\title{
Capitalism in Central Norrland, Sweden, during the Iron Age
}

\author{
Henrik von Stedingk \& Evert Baudou
}

\begin{abstract}
The authors challenge the opinion that a traditional hunter-gatherer culture existed during the Iron Age in the forested interior of central Norrland (En. Northern Sweden). Two new and several earlier pollen analyses together with osteological finds from domestic animals confirm that extensive forest grazing was widespread throughout the interior. The distribution of iron slag deposits suggests that iron production is a key factor to understanding the society in the area. The modes of subsistence, the low-technology ironwork, and a common conceptual world as reflected in the graves on the coast and in the interior can be viewed as elements of an early capitalistic system.
\end{abstract}

Henrik von Stedingk, Department of Forest Vegetation Ecology, SLU. Swedish University of Agricultural Sciences, SE-901 83 Umea, Sweden.

Evert Baudou, Department of Archaeology and Sami Studies, Umeå University, SE-901 87, Umeå, Sweden.

Key words: Vegetation history, pollen analysis, land use, forest grazing, animal husbandry, iron production, graves, conceptual world, archaeology.

In research on the Iron Age in central Norrland (En. Northern Sweden), the great barrows ( $\mathrm{Sw}$. storhögar) and burial-grounds of the coast and the area around Lake Storsjön together with the well-known farmsteads have been set in contrast to the sparsely distributed and simple Iron Age graves by the inland lakes. Often archaeologists draw a distinction between an agrarian culture in the arable coastal tracts and a traditional, northern hunting culture in the inland forests (Selinge 1979, 1983, 1994:32-33; Ambrosiani et al. 1984:62-63; Hyenstrand 1987:114115, 152-156; Zachrisson 1997a:224-228, 2004:10). However, there are features in the picture offered by archaeological findings, and even more in the one offered by environmental history studies, that are incompatible with this dualism.

Since the 1970s findings have been published that contradict the impression of a traditional hunting culture that endured until the Middle Ages in the interior of central Norrland. Among them are pollen analyses that indicate continual forest grazing from around AD 1 in inland Medelpad (Engelmark 1978), as well as major deposits of Iron Age iron slag by lakes (Magnusson 1986) and osteological determinations of sheep/goats in graves around lakes (Sundström 1994, 1997; 
Bolin 2001). Gert Magnusson adopted a broad perspective (1986) and linked the early iron production that he had demonstrated in Jämtland-Härjedalen to the total use of forest resources. In his presentation of the development of agriculture during the Neolithic and Bronze Age, Stig Welinder (1998:188-189, 194) pointed to results of pollen analyses and declared that cattle grazed the slopes of Härjedalen during the Late Neolithic, and that grazing may already have begun in inland Hälsingland and the Storsjön area in Jämtland in the early Bronze Age. There is, however, little knowledge of Iron Age settlements near lakes even though some have been located (Sundström 1994:109-111, 1997:24-25).

A new starting point is provided by the findings of multi-disciplinary studies of the cultivation of marginal land in the northern areas of Värmland-Dalarna and central Norrland (Svensson 1998; Emanuelsson 2001; Liases 2003). Animal husbandry was already taking place during the Iron Age in the areas studied, and not merely hunting, fishing and gathering. Exploiting iron was also important. A more discriminating approach than in earlier research can already be discerned in the title of the multidisciplinary project "Flexibility as tradition", which for a number of years has been focusing on the Iron Age and the historical period at Ängersjö in north-western Hälsingland (Emanuelsson 2001:8-12; Johansson 2002).

In general it can be said that there are two opposing views on Iron Age modes of subsistence and culture in the interior of central Norrland. One is that a traditional hunting culture prevailed until the $12^{\text {th }}-13^{\text {th }}$ centuries. The other is the belief that modes of subsistence, economies and cultures were characterised by great flexibility. The latter belief places a stronger emphasis on environmental studies than does the belief advocating traditional hunting cultures. Our study aims to appraise the conditions that existed for flexible modes of subsistence and economies. All ethnic and linguistic interpretations will be disregarded. Our hypothesis is as follows:

Forest grazing has provided a general basis for subsistence in the interior of central Norrland during the Iron Age.

Two pollen analyses were undertaken in northern Ångermanland, an area where this kind of study has not been conducted to the same extent as in the more southern areas of central Norrland. The analyses involved taking samples from small mires which better reflect changes in the local vegetation (Jacobsson \& Bradshaw 1988; Sugita 1994). These mires are remote enough from excavated archaeological sites to be able to reflect usage of the forest rather than activities at settlements. The pollen analyses are related to earlier research on archaeological finds and prehistoric remains and to the geographical distribution of deposits from iron working in central Norrland. The concluding discussion concerns the extent to which the interaction of modes of subsistence, ideology and economics during the first millennium $\mathrm{AD}$ could be characterised as a form of capitalism based on the production and distribution of iron. The concept of capitalism refers here to the use in North American historical archaeology (Leone 1999). 
In North America, modern historical archaeology has adopted the study of capitalism as one path towards understanding problems in the archaeology of the historical period (Leone \& Potter 1999). The inception of capitalism is ascribed to Renaissance Europe. If that were the case, it would be inappropriate to discuss capitalism in central Norrland during the Iron Age, where the historical situation was very different from that of $15^{\text {th }}$-century Europe. But if we reflect on the content of a basic definition of capitalist society given by Mark P. Leone (1999:4), we can consider whether this definition of the concept can help us to understand totally different prehistoric circumstances (see "Iron and capitalism" below).

\section{FORESTLAND AS RESOURCE DURING THE IRON AGE}

Pollen analysis and study sites

The palaeoecological investigations were performed in two areas in the northern part of the province of Angermanland (Fig. 1). The areas are mainly forestland, outside the agrarian areas, and in archaeological terms they are called hunting grounds. The study sites were chosen on the basis of two main criteria: the distance from excavated archaeological sites, and the size of the mire. The sampling sites had to be close enough to the archaeological sites for the forestland to have been used for grazing, but distant enough to record a pollen signal reflecting the forestland's use rather than the settlement (Hicks 1985; Emanuelsson 2001:18). By taking samples from small mires, i.e., about one hectare in size, plants growing close to the sampling point will have a stronger representation in the pollen diagram (Sugita 1994).

The first study site, Råmyren, is situated one $\mathrm{km}$ north of the excavated settlement of Råinget I (Ådalsliden parish Raä 123) (Fig. 1). The excavation at Råinget gave a rich archaeological material from c. $2000 \mathrm{BC}-\mathrm{AD} 1000$ (George 2001). Radiocarbon dates of remains of cattle indicate animal husbandry during

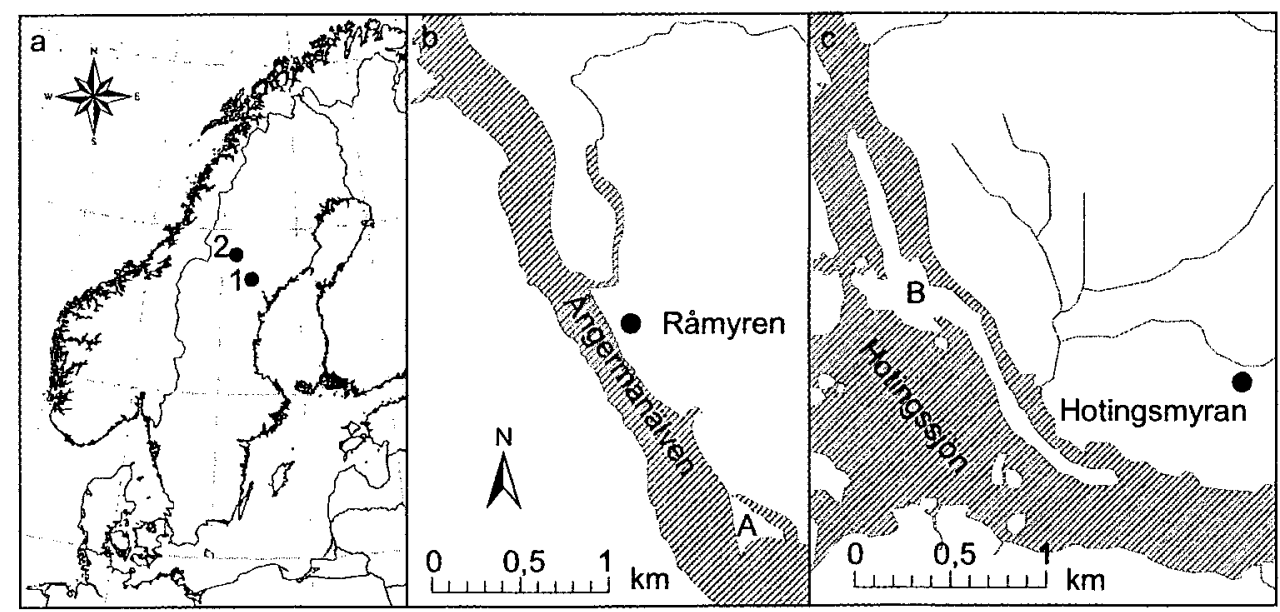

Fig. I. Map of Scandinavia showing the sample sites Ramyren (1) and Hotingsmyran (2). Map with the sample sites (•) and the archaeological sites Råinget $(A)$ and Långön (B). 
the late Iron Age. Råmyren is situated $3 \mathrm{~km}$ north-west of Nämforsen, on a small plateau on the north-eastern slope of the river valley, $200 \mathrm{~m}$ from the Angermanälven river bank.

The second study site is a mire by Lake Hotingssjön, Tåsjö parish, which belongs to the Fjällsjöälven river system (Fig. 1). Many settlements from c. 5000 BC-AD 1 are known from the shores of Lake Hotingssjön and other lakes in the neighbourhood. On Långön, an island in Lake Hotingssjön, there is a burialground in which 11 low burial mounds from the Viking Age have been excavated (Tåsjö parish, Raä 155a). This is the northernmost burial-ground of Viking Age type in Sweden (Hvarfner 1957, 1966; Ambrosiani et al. 1984:62-63; Zachrisson 1994, 1997b:24-228; Bolin 2001:22). There are some remarkable finds of imported objects which testify to trade and exchange relations with more distant parts of Scandinavia, but no finds relate to the local land use. The site at Hotingsmyran, situated on the mainland $2 \mathrm{~km}$ east of Långön, is a small mire, one hectare in size, and covered with a multi-layered mixed forest of spruce (Picea abies) and deciduous trees.

\section{Vegetation history}

Based on the major changes in the two pollen diagrams (figs. 3 and 4) three vegetation periods (zones) have been identified: A) natural forest, the time period prior to human impact; B) the introduction of forest grazing; and C) increased land use with grazing, haymaking and cereal cultivation. The age determination is based on age/depth curves that are in turn based on calibrated AMS ${ }^{14} \mathrm{C}$-dating of selected bulk samples (table 1 and Fig. 2).

A. Natural forest (Råmyren prior to $\mathrm{AD} 100-400$; Hotingsmyran prior to 500 $200 \mathrm{BC})$

The forest was composed of a mix of boreal tree species such as Pinus, Picea, Betula and Alnus. The most important vegetation change during this period was the development of spruce forests. At Hotingsmyran Picea became common around $800 \mathrm{BC}$ and increased in importance about 500-200 $\mathrm{BC}$. The tree pollen

\begin{tabular}{|c|c|c|c|c|}
\hline $\begin{array}{l}\text { Laboratory } \\
\text { code }\end{array}$ & Site & $\begin{array}{r}\text { Depth } \\
\mathrm{cm}\end{array}$ & ${ }^{14} \mathrm{C}$-age & $\begin{array}{l}\text { Calibrated age: intercept and } \min \text { and } \\
\text { max ranges at } 2 \text { sigma }\end{array}$ \\
\hline Ua-19588 & Råmyren & 54 & $825 \pm 55$ & $1041-1286$ AD (1220 AD) \\
\hline Ua-17590 & Råmyren & 90 & $1575 \pm 75$ & $\begin{array}{l}262-642 \mathrm{AD}(439,451,464,504,506, \\
518,528 \mathrm{AD})\end{array}$ \\
\hline Ua-19589 & Råmyren & 107 & $1790 \pm 55$ & 84-391 AD (240 AD) \\
\hline Ua-16818 & Hotingsmyran & 36 & $405 \pm 70$ & 1408-1652 AD (1454 AD) \\
\hline Ua-19590 & Hotingsmyran & 42 & $2105 \pm 55$ & $354 \mathrm{BC}-19 \mathrm{AD}(154,133,117 \mathrm{BC})$ \\
\hline Ua-18069 & Hotingsmyran & 53 & $2310 \pm 70$ & $534-200 \mathrm{BC}(393 \mathrm{BC})$ \\
\hline Ua-19591 & Hotingsmyran & 60 & $2375 \pm 50$ & $758-381 \mathrm{BC}(403 \mathrm{BC})$ \\
\hline
\end{tabular}

Table $1 .{ }^{14} \mathrm{C}$-dates and calibrated ages from the peat samples from Ramyren and Hotingsmyran. The AMS analyses were made by the Angström Laboratory, Uppsala. The calibrations were made with the program Calib 4.2 (revised version of Calib 3.0; Stuiver \& Reimer 1993). 


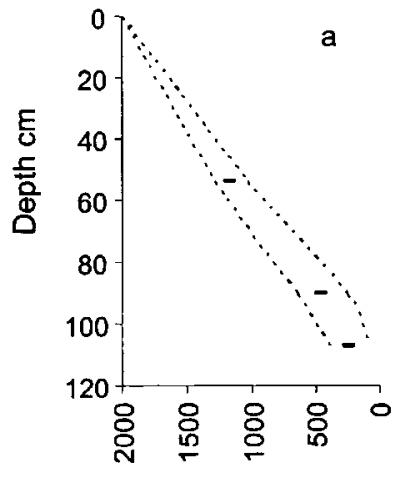

Calibrated age A.D.

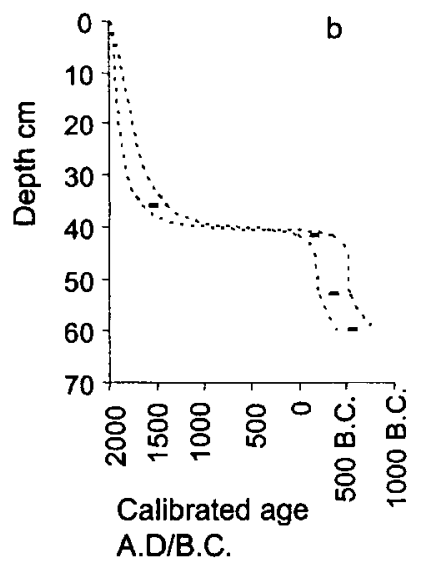

Fig. $2 a$ and $b$. Age/depth curves expressed as calibrated ${ }^{I 4} C$ ages $A D / B C$ for the peat cores from Ramyren (figure 2a) and Hotingsmyran (figure 2b). The lines show the minimum and maximum age ranges at 2 sigma. The horizontal short lines mark the depths where the ${ }^{14} \mathrm{C}$ samples were taken. The age/depth model from Raimyren shows that the peat accumulation has been rather stable through the whole stratigraphy. In the Hotingsmyran age/depth model there is a change in peat accumulation between the two upper ${ }^{14} \mathrm{C}$ datings at 36 and $42 \mathrm{~cm}$ depth. Either this is a result of a change in peat accumulation rate or there is hiatus in the peat statigraphy.

amounts to $95-100 \%$ and thus indicates that the forest was closed. The ground flora included dwarf shrubs and a small proportion of grasses. Non-flowering plants such as Polypodiaceae and Lycopodium were frequent, and at Hotingsmyran Equisetum was also common. These species may have grown on the mire; however, they are also a natural component of the boreal forests. At Råmyren Cyperaceae were very common on the mire.

In neither of the pollen diagrams are there any signs of human impact. Either human activity was only very small scale, or it was too distant from the sampling sites to be recorded (Hicks 1991). Forest fire is a part of the natural disturbance regime of the boreal forest (Zackrisson 1977) and human presence is normally expected to alter the fire regime, either accidentally or on purpose (Niklasson \& Granström 2000), causing a change in charcoal deposition. However, the frequency of charcoal in these records is low, thus suggesting low impact from forest fires in general.

B. Extensive forest grazing (Råmyren AD 100-400 to 1000-1300, Hotingsmyran $\underline{500--200 \mathrm{BC} \text { to AD 1300-1500) }}$

Rumex, Melampyrum, Ranunculus, and Poaceae were growing on both sites, and at Råmyren also Artemisia and Juniperus. All these taxa are related to disturbance and more open conditions, and Poaceae, Juniperus and Rumex are all species favoured by grazing (Behre 1981; Segerström et al. 1996). Also dwarf shrubs were important in the field layer at both sites. At Hotingsmyran Picea decreased markedly during the period. The mire developed into a deciduous fen with Betula and Alnus. Macroscopic wood remnants in the peat stratigraphy also support the 


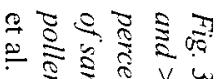

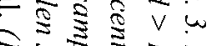

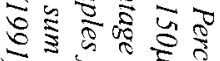

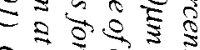

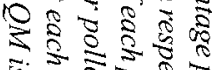

$\therefore$ क $2: 3$

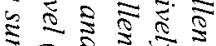

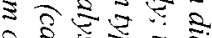

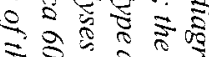

空 8

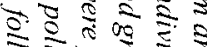

$\frac{2}{2} \frac{2}{2}$.

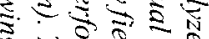

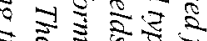

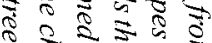

दे है

है

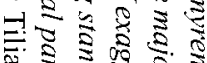

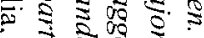

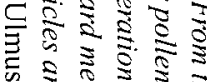

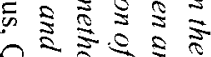

๕)

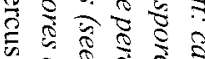

ग)

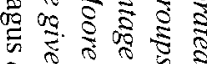

8925

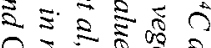

की

을 5

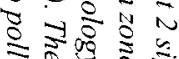

ह 0 क

5 5

ฐ

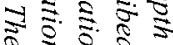

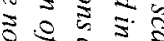

จ 8 is

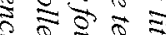

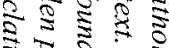

2.

8 है 25

$8 \underset{2}{2} \stackrel{2}{5}$

क्षे कर

ㄷ. हक

웡

Q.

$\frac{2}{2} \div \frac{2}{2}$

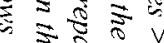

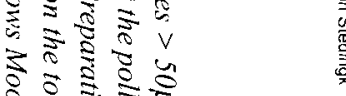
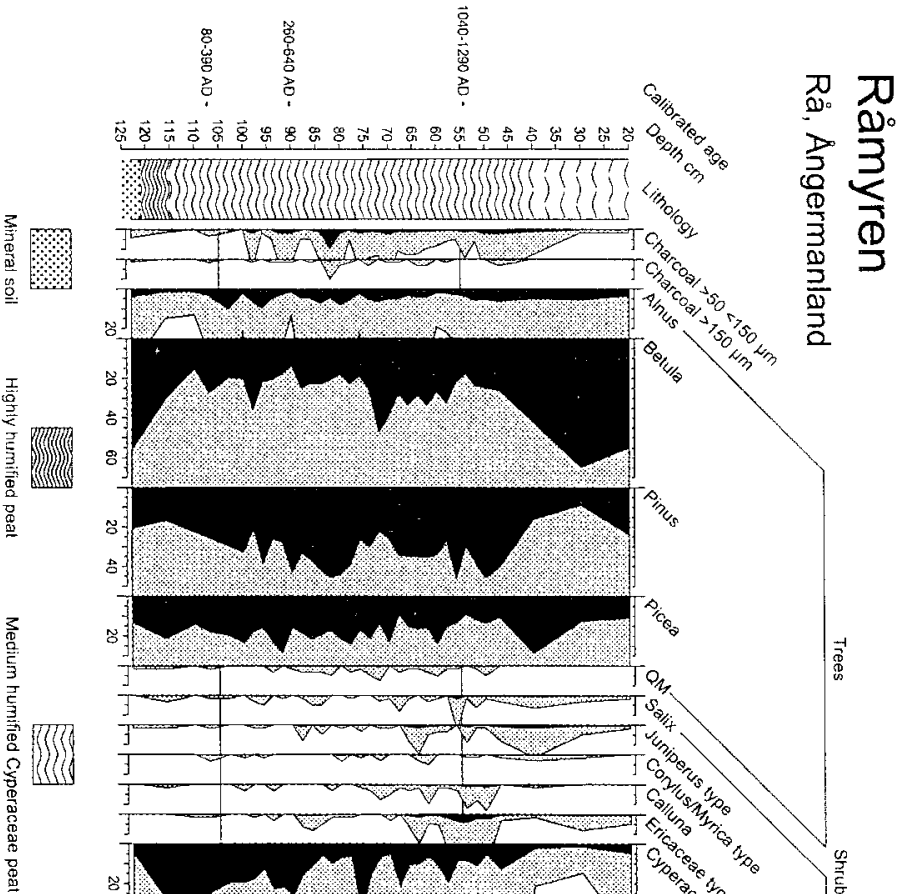

送
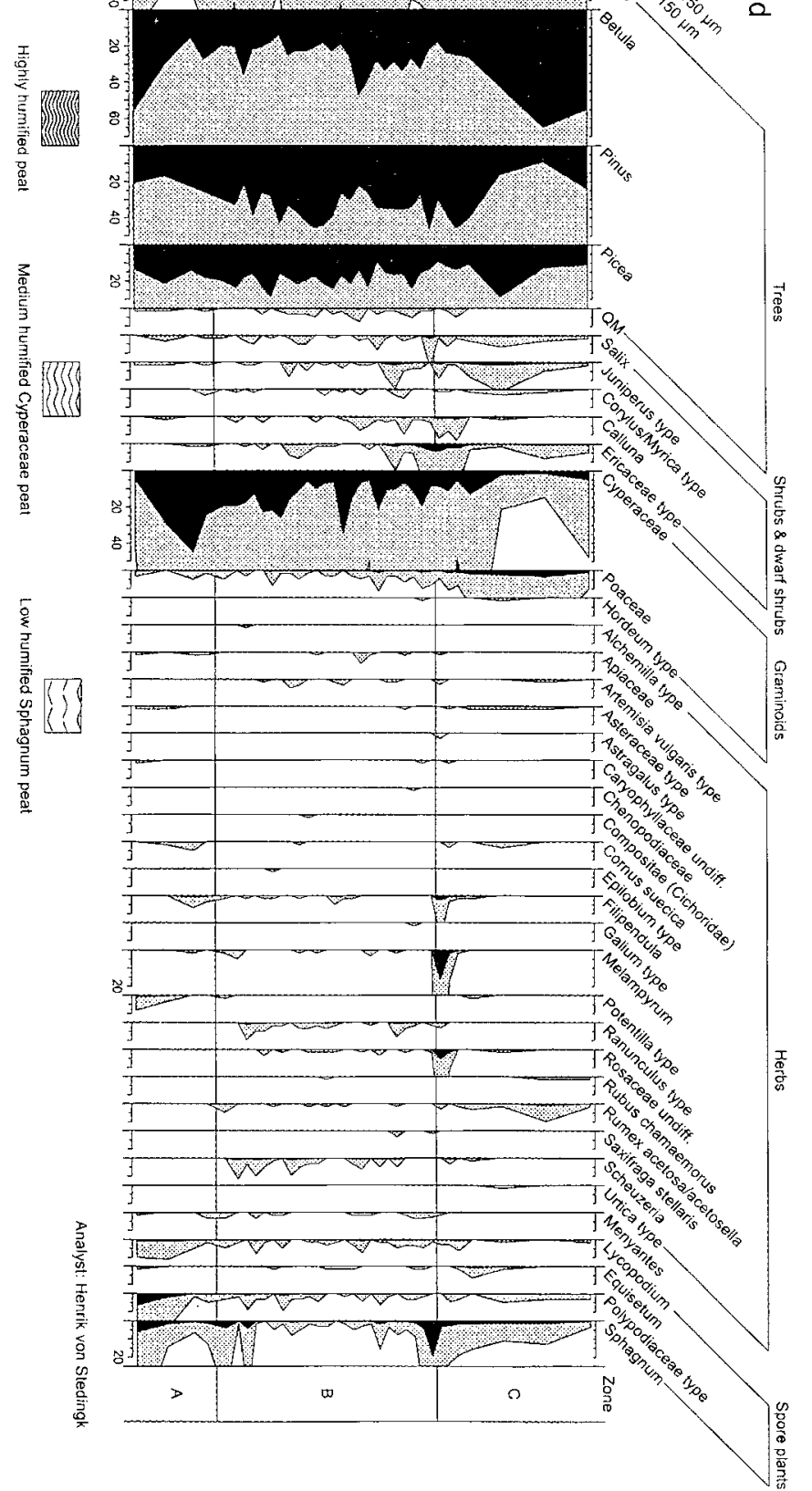


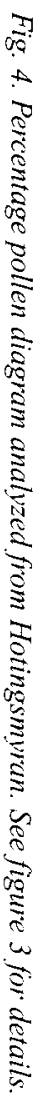

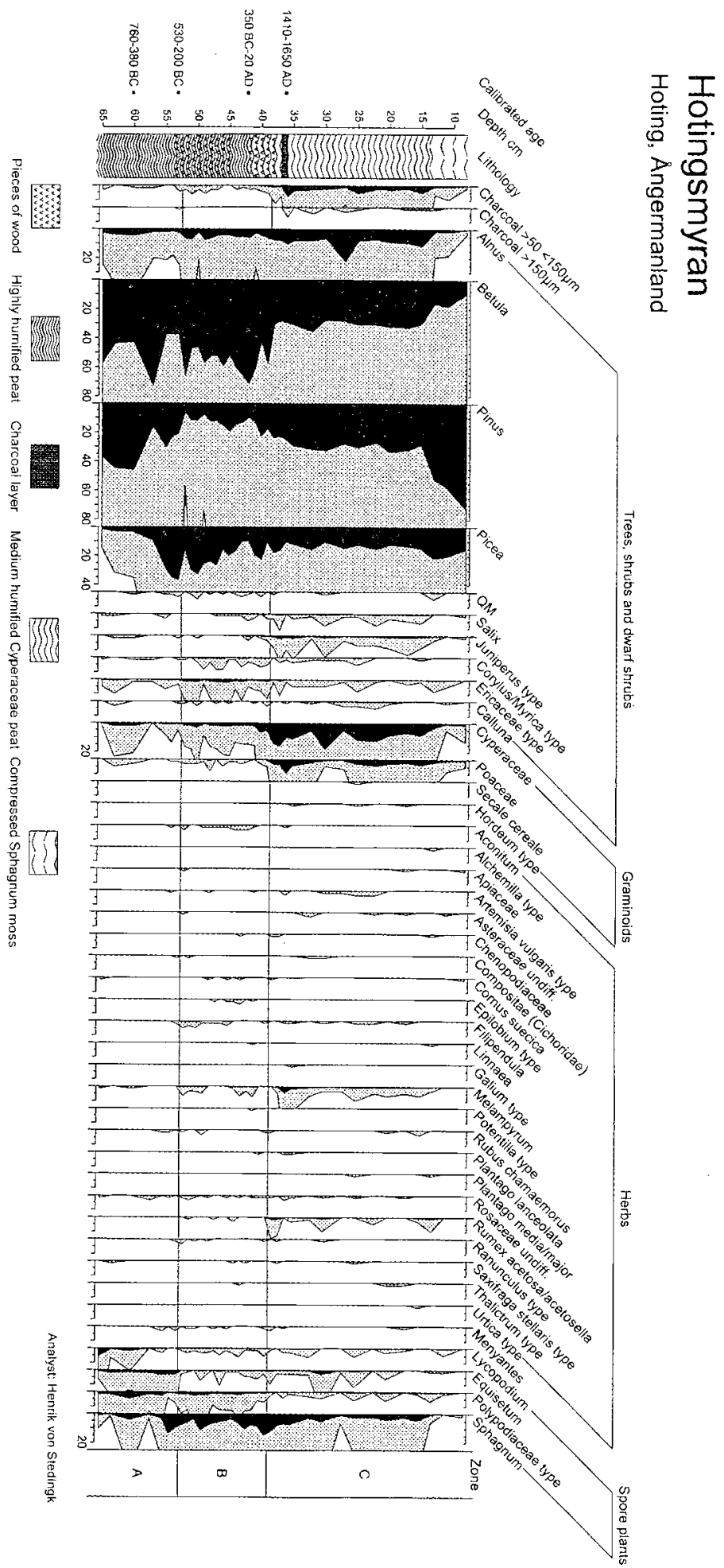




\begin{tabular}{|c|c|c|c|}
\hline Site & Osteological finds & Period & Reference \\
\hline $\begin{array}{l}\text { Klevsand, Idsjön, } \\
\text { Jämtland }\end{array}$ & $\begin{array}{l}\text { Antler fragment of } \\
\text { sheep/goat, human } \\
\text { bones }\end{array}$ & $\begin{array}{l}\text { Late Roman Iron } \\
\text { Age or early Migra- } \\
\text { tion Period }\end{array}$ & Sundström 1994:105, 1997:23 \\
\hline $\begin{array}{l}\text { Backnorholmen, Rev- } \\
\text { sundsjön, Jämtland }\end{array}$ & Dog, human bones & Migration Period & Sundström 1994:105, 1997:23 \\
\hline $\begin{array}{l}\text { Tjuvholmen, Storsjön, } \\
\text { Jämtland }\end{array}$ & Pig, human bones & Migration Period & $\begin{array}{l}\text { Magnusson 1986:73-74; } \\
\text { Sundström 1994:104, 1997:22 }\end{array}$ \\
\hline $\begin{array}{l}\text { Rödön, Storsjön, } \\
\text { Jämtland }\end{array}$ & Dog, human bones & Viking Age & $\begin{array}{l}\text { Magnusson 1986:70, } \\
\text { Sundström 1994:106, 1997:23 }\end{array}$ \\
\hline $\begin{array}{l}\text { Båganäset, Ansjön, } \\
\text { Jämtland }\end{array}$ & $\begin{array}{l}\text { Sheep/goat, human } \\
\text { bones }\end{array}$ & Viking Age & Sundström 1994:106, 1997:23 \\
\hline $\begin{array}{l}\text { Holmsjön, Haverö } \\
\text { parish, Medelpad }\end{array}$ & Dog, human bones & Viking Age & Hjortsberg 1978:15 \\
\hline $\begin{array}{l}\text { Långön, Hotingssjön, } \\
\text { Ångermanland }\end{array}$ & Dog, human bones & Viking Age & Zachrisson 1994:154 \\
\hline $\begin{array}{l}\text { Vikarsjön, Hede } \\
\text { parish, Härjedalen }\end{array}$ & $\begin{array}{l}\text { Sheep/goat, human } \\
\text { bones }\end{array}$ & Early $13^{\text {th }}$ century & $\begin{array}{l}\text { Sundström 1994:108, } \\
\text { 1997:23-24 }\end{array}$ \\
\hline
\end{tabular}

Table 2. Excavated Iron Age graves in inland central Norrland with burnt bones of domestic animals.

conclusion that trees were growing on the mire. The development of a deciduous fen is the main explanation for the rise in birch pollen, with the ensuing suppression of the Pinus pollen frequencies in particular but also of Picea, rather than being indicative of a major shift in species composition in the forest around the site. At Råmyren there were no major changes in species composition of trees, and Picea decreased only slightly during the period. The mire remained open and characterised by Cyperaceae. At both sites an increased frequency of charcoal is recorded. At Råmyren the charcoal frequency is high and includes fragments bigger than $150 \mu \mathrm{m}$. Charcoal particles of this size do not spread very far from their source and therefore indicate more local or on-site fires (Pitkänen et al.1999; Ohlsson \& Tryterud 2000). At Hotingsmyran the frequency of charcoal is lower and no larger charcoal fragments are recorded, but the presence of Epilobium, a species commonly favoured by fire, suggests that local forest fires also occurred here. The signs of forest grazing are strong at Råmyren. At Hotingsmyran the indications for forest grazing are weaker, and the date for the start of forest grazing at Hotingsmyran is remarkably early. But altogether, the increase in species favoured by grazing as well as the charcoal records suggests that these forests were utilised for extensive forest grazing (Segerström et al.1996).

C. Increased land use; forest grazing, haymaking and cereal cultivation (Råmyren AD 1000-1300 to present, Hotingsmyran AD 1300-1500 to present)

A marked vegetation change records the start of more intensive land use. Poaceae, Juniperus and Rumex, which all are favoured by grazing, increased. At both sites 
Melampyrum became more common and at Råmyren there was also an increase in Filipendula and Rosaceae. The ephemeral increase in these herbs suggests that the forest was opened up and more light reached down to the forest floor. Dwarf shrubs were still common in the field layer.

The charcoal records indicate that fire played a prominent role in the forest. At Hotingsmyran there is a high frequency of charcoal and also charcoal fragments larger than $150 \mu \mathrm{m}$, which indicate local fire impact. At Råmyren charcoal particles are frequent in the first half of the period. In addition to grazing and burning for pasture improvement, other types of land use were also introduced. The formerly deciduous fen at Hotingsmyran was transformed into sedge mire. Trees that grew on the mire were removed, the hydrological conditions were altered, and the mire was used for haymaking (Elveland 1979; Segerstöm \& Emanuelsson 2002). The age/depth model (Fig. 2b) suggests that the peat accumulation rate changed radically; either peat from the period c. AD 1-1000 is missing or peat accumulated much more slowly during this period. Growing hay on mires could result in a much lower peat accumulation rate due to the removal of large quantities of biomass and a change in species composition in bryophytes from Sphagnum to much slower peat-producing brown mosses (Elveland \& Sjöberg 1981). In the initiation phase it was also common for the Sphagnum layer to be removed by humans, and changed hydrology and more intensive light could result in compression of the peat (Elveland \& Sjöberg 1981). Both a hiatus in the peat stratigraphy and a much slower peat accumulation would support the assumption of the start of more intensified land use. The cereal pollen suggests that cultivation began in the area. The few grains of cereal pollen recorded most likely reflect agriculture at settlements in the area, rather than cultivation in the forest.

The pollen diagram from Hotingsmyran extends to the present day, and a marked vegetation change is reflected in the upper part, c. AD 1900. There is a decrease in the taxa favoured by grazing as well as in the frequency of charcoal, whereas the Pinus frequency increases. Sedges are no longer characteristic for the mire. These changes are interpreted as a shift in land use from mainly animal husbandry to forestry and timber production.

\section{GRAVES AND IDEOLOGY, ANIMAL BONES AND ECONOMY}

At the lakes in central Norrland and in the province of Dalarna about 700 Iron Age grave-settings have been registered (Selinge 1994:33). Of these about 20 have been excavated in central Norrland. Two cultural traditions can be seen:

1. Graves in which burnt bones of domestic animals are found together with burnt human bones. Grave-goods are frequent.

2. Graves in which unburnt bones and antlers of elk and reindeer are deposited on the surface of the grave fillings, of elk only crania and antlers. The burnt human bones are not mixed with animal bones. Grave-goods are missing or are few and inconsiderable. 
The first tradition comprises sparse and scattered stone-settings and small mounds, occasionally in small burial-grounds, on the shores of inland lakes. Graves with burnt bones of domestic animals together with burnt human bones occur from the first centuries $\mathrm{AD}$ to the beginning of the $13^{\text {th }}$ century (table 2 ).

There are a number of external differences between grave-settings on the coast and in the interior. Opinions differ as to what these variations mean (e.g. Bolin 2001:18). It transpires that the significance of grave-settings both on the coast and in the interior differs from that of graves in the more recent sense of the word (Baudou 2002:26-27). The mounds and stone settings studied on the central Northern Swedish coast contain one grave, sometimes two. This means that the number of known grave-settings is too small to correspond to the population that could reasonably be expected in viable settlements. The number of known gravesettings at settlements that existed in Ångermanland and Hälsingland for 400500 years is so low that only one individual in every generation has been interred (Baudou 1991:71). Our modern concept of "grave" does not embrace the significance of the settings from the Roman Iron Age and the Migration Period in the coastal regions of central Norrland. It has been proposed that these mounds were the sacred places of the settlements and were linked to an ancestral cult (Baudou 1989, 1991). In addition, the great barrows have always been regarded as indications of social power and ownership. In the area around Lake Mälaren in central Sweden, on the other hand, the burial-grounds of the period with their closely packed graves are large enough to yield a number of burials commensurate with reasonable population figures. In the interior of central Norrland the sparsely distributed graves suggest that ideological concepts are the same as those on the coast. This means that both the coast and interior of central Norrland differ from the Mälaren region during the Roman Iron Age and Migration Period, but indicate links with western and south-western Norway, where the same burial systems occur. There is also a major difference from northern Norrland where graves are, on the whole, very unusual during this period (Fig. 8).

Examples of the second tradition can be found in the burial-grounds at Krankmårtenhögen and Smalnäset in Härjedalen. At these sites there were 30 and 34 stone-settings, respectively, closely packed and triangular or round in shape, dating from the end of the pre-Roman and the early Roman Iron Age (Ambrosiani et al. 1984). Unburnt skulls and antlers from elk and reindeer lay above these stone-settings, and bones of bears were even found on two of the settings. Domesticated animals were represented by a single, unburnt tooth from sheep/goat (Ambrosiani et al. 1984:71). At Krankmårtenhögen four elk skulls found on top of a triangular stone-setting have been ${ }^{14} \mathrm{C}$-dated, yielding the central values of $\mathrm{AD}$ 85, 145, 210 and 275 (Ambrosiani et al. 1984:32, 56). None of the reindeer bones or antlers has been dated, but the circumstances in which they were found suggest that they date from the same period as the elk skulls. Burnt animal bones never lay together in the graves with burnt human bones. On the other hand, at both burial-grounds burnt elk bones had been placed in a number 
of stone-settings in which there were no human bones. These have been interpreted by Ambrosiani as "sacrifices to or substitutes for a dead person" (Ambrosiani et al.1984:54). Three later finds of unburnt elk or reindeer bones at two stonesettings and a cairn at Tärna in Lapland (Bolin 2001:15-17) differ totally from the burial-grounds in Härjedalen.

The two large burial-grounds in Härjedalen correspond in terms of the shape of the graves and the structure of the sites to burial-grounds in Dalarna and the Mälaren area (Bellander 1939:26-31; Ambrosiani 1964:66-68). There is nothing similar to the north or in the coastal areas of central Norrland. In order to find parallels to the custom of sacrifice Zachrisson (1997b:197-199) has turned to more recent rituals among peoples in northern Eurasia and to the deposits of antlers in Mesolithic graves in Northern and Western Europe. However, the sacrifice of unburnt skulls of animals was a frequent practice during the prehistoric period in the Mälaren area and further south (Ullén 1994:252-254; Hårding \& Kraft 1997:69; Hårding 2005:156-158). The elk skulls sacrificed in Härjedalen can be viewed as a tradition from the Stone and Bronze Ages in Norrland, when the elk played a central role in everyday life as well as conceptually, judging from the many elk bones found in hearths and from rock art. The other form of sacrifice at the two burial-grounds - the burnt elk bones in the stone settings which contain no human bones - has been viewed as an example of Arctic animal ceremonies (Zachrisson 1997b:200). However, there are comparisons closer to hand. In the enclosure (prehistoric fort) at Odensala Rectory in Uppland, dated to c. 800-200 BC, 12 of the 26 grave-settings contained only animal bones (Olausson 1995:212216). The graves with animals never contained burial gifts, but on the other hand combinations of cattle, horses and pigs. In five settings sheep/goats were the only animal. How common this sacrificial ritual was is not known. In both Uppland and Härjedalen the animals that meant most for survival had been sacrificed in graves of their own that resemble human graves. The cultural tradition reflected in the graves and the finds at Krankmårtenhögen and Smalnäset have widespread cultural precedents, most closely in the Mälaren area and further south, as well as roots in the local culture of Norrland.

The two traditions in central Norrland with their different kinds of osteological finds have different origins and different chronological and geographical distributions. Both traditions involve an interaction of mode of subsistence and a conceptual world or ideology that is reflected in the graves and the sacrifices. The first tradition is most important and is related to the sparsely distributed inland grave-settings that are linked to the coastal settlements.

\section{FOREST GRAZING - THE LINK BETWEEN POLLEN ANALYSIS AND ARCHAEOLOGY}

The two study sites are both situated a few kilometres from excavated prehistoric settlements. Råmyren is one $\mathrm{km}$ north of the settlement Råinget $\mathrm{I}$, which was excavated by Gustaf Hallström in 1946 in conjunction with the hydroelectric 
project at the rapids of Nämforsen (George 2001). In places the earth layer was $90 \mathrm{~cm}$ deep and good stratigraphical observations were possible. According to seven ${ }^{14} \mathrm{C}$-dates of potsherds the settlement was inhabited from c. $2000 \mathrm{BC}$ to the centuries around AD 1 (Forsberg 2001:Fig. 6). Some iron objects are dated to the late Iron Age. The most recent pottery consists of ceramics tempered with asbestos, i.e., asbestos ware, with comb-stamped ornamentation. The asbestos ware is connected with an early technique for iron production on a small scale (Hulthén 1991:34). This early use of iron in the interior of northern Norrland for the production of small objects led to a reduced use of stone as raw material. It is impossible to know whether the settlement was continuously inhabited. Radiocarbon analysis of a bovine tooth indicates animal husbandry c. AD 640-960 (Lindqvist 2001:97-98). One bone fragment from a dog was found in a late layer. Unburnt bones of cattle were also found at the nearby settlement of Rainget II, together with burnt bones (Iregren 1984:70).

The forests around Råmyren were not influenced by any marked anthropogenic disturbance until c. AD 200, the time period identified as the start of local forest grazing. It seems reasonable to believe that it was people living at Råinget who used the forest as pasture. There were probably links between the land use of Råinget/Råmyren and the settlement at Nämforsen, $3 \mathrm{~km}$ down the Ångermanälven river, where animal husbandry has been inferred to judge from pollen and cattle remains (Huttunen \& Tolonen 1972:15-16; Lindqvist 2001:97-98). The Råmyren diagram tells us about the land use around the site, but in order to set an initiation date for forest grazing in a wider region including Råinget and Nämforsen, additional pollen analyses must be performed from the area. In the western valley of Angermanälven river Ådalsliden became a parish at the beginning of the $14^{\text {th }}$ century, which corresponds to the intensified land use reflected in the pollen diagram.

The other sample site, Hotingsmyran, is situated at Lake Hotingssjön where about 90 shore settlements are known, dating from the Mesolithic to the centuries just before or after AD 1. Eight of these settlements have been studied by excavating separate trenches. The burial-ground on Långön is dated to c. AD 900-1200, but no settlements are dated to the period from the first centuries AD to the Middle Ages. At ten or so shore settlements ceramic sherds of various kinds have been found, the most recent asbestos ware with comb-stamped ornamentation as at Råinget. The burnt bones found at these settlements come mainly from elk and beaver, but no domesticated animals. However, pollen analysis reveals grazing as early as $500-200 \mathrm{BC}$. Who used the forest around Hotingsmyran? Was it people from the shore settlements, or others whose settlements are unknown? Where did the people using Långön as a burial site live? In the pollen diagram the beginning of the grazing period is well dated, as is the time when this use became more intensive. Disruptions in the stratigraphy of the peat make it impossible to determine with any certainty whether the grazing was continuous during the period 400 BC-AD 1500 (Fig. 4). 
Knowledge of inland Iron Age settlements is deficient. Excavations in JämtlandHärjedalen have often disclosed hearths which have been ${ }^{14} \mathrm{C}$ dated as Iron Age at sites that otherwise belong to the Stone Age or Bronze Age (Sundström 1997:2425). There are few or no Stone Age finds close to the hearths; occasionally there are objects of iron. One hearth of this kind dated to AD 750-915 was found at a Stone Age settlement at Bölensvattnet in Bodum, about $20 \mathrm{~km}$ south of Långön (Baudou 1978:92). In order to use the hearths and the finds in this discussion a distinction must be made between the Iron Age settlement and the remains of the surrounding Stone Age settlement, which requires new excavation or analysis of known material. Pollen analysis from Hotingsmyran indicates that the area was used for extensive grazing, which makes it even more important to look for the inland Iron Age settlements.

The name Hotingssjön is known from the end of the $13^{\text {th }}$ century, but there were no permanent buildings before the $17^{\text {th }}$ century. The period of hay production at Hotingsmyran coincides with historical information that the area was used for pasture and haymaking during the $16^{\text {th }}$ century by a settlement some distance away (Modin 1961:126).

Archaeologists often make use of pollen analysis as a method of corroborating the archaeological findings. The idea of forest grazing and animal husbandry as an important form of subsistence in the interior of central Norrland during the Iron Age has, however, been hard to accept. The obstacle is the dualistic view which regards the inland region as hunting grounds, while the cultivable coastal region was inhabited by farmers. Nevertheless, palaeoecological investigations published since the 1970s have shown that inland subsistence was not based entirely on hunting, fishing and gathering (Engelmark 1978). Instead of indicating land use that supports the archaeological investigations (cf. Emanuelsson 2001:1719), pollen analyses suggest land use that is not archaeologically observable, such as extensive forest grazing in the area around Hotingsmyran during the Iron Age.

At first glance the early dates for forest grazing at Hotingsmyran, situated in an area considered as hunting ground at the time, might seem surprising. It is even more so in comparison to the later dates of forest grazing at Ramyren, located in Adalen, an area rich in archaeological remains. A reasonable interpretation of the different dates for forest grazing at the two sites might be that forest grazing was practised in the region already from the early Iron Age, but that the individual sites, and the time of change in land use, rather reflects the use around each mire. Several analyses show that forest grazing was widespread in the Iron Age landscape (Fig. 5). The sites of osteological finds of goat/sheep are widely dispersed throughout the landscape (table 2). These animals also feed on shrubs and trees, and in rather small numbers they can affect the forest in the way reflected in the diagrams.

Why can it not be reindeer grazing? Firstly, the vegetation changes indicating grazing are continuous already from the start of registration, and not periodic. 


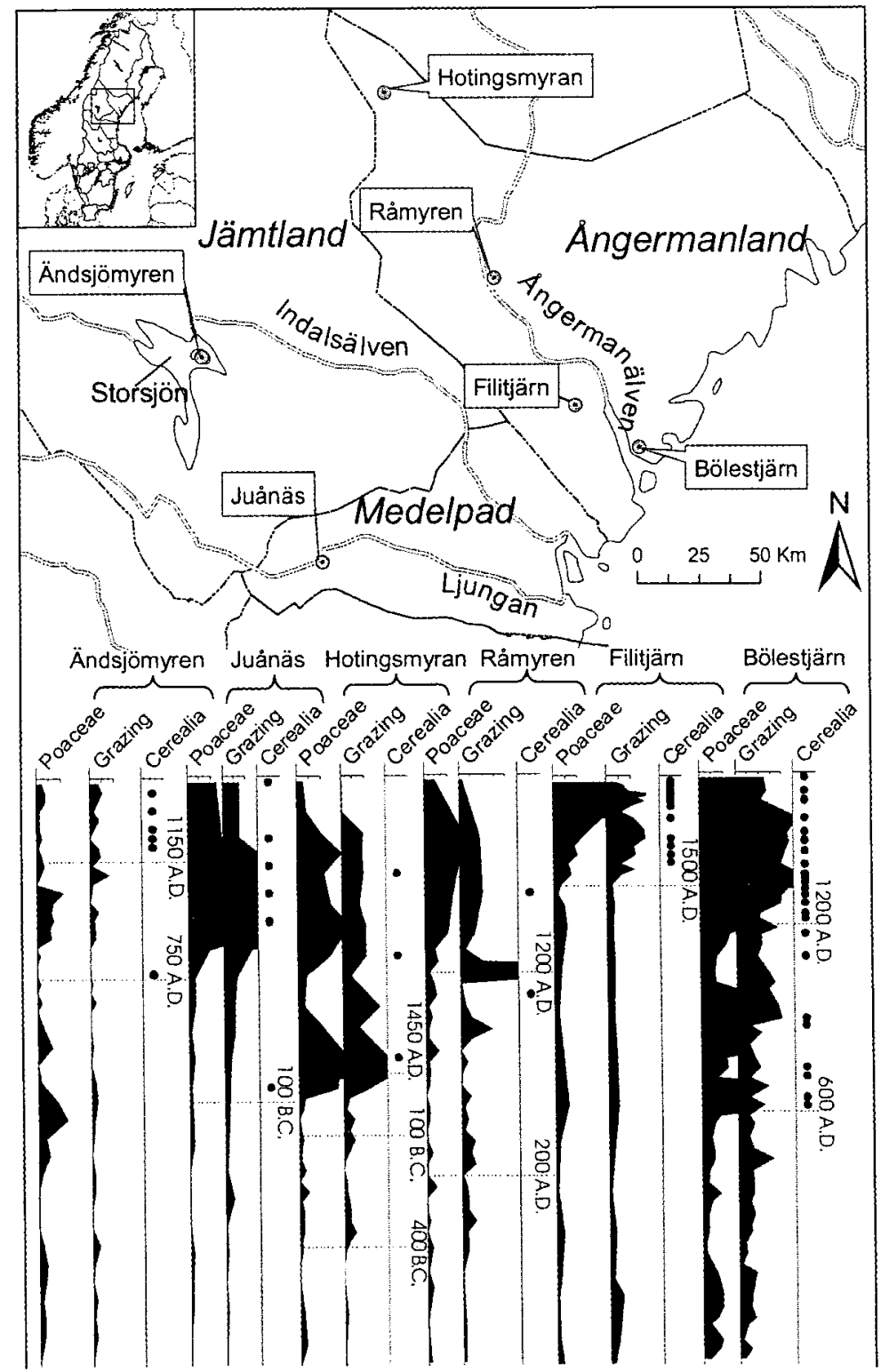

Fig. 5. A map showing the land-use as a east-western transect based on several pollen analyses. The pollen diagrams show frequency (each scale mark represents one percentage) of selected taxa based on the total pollen sum of each individual diagram: Ändsjömyren (Wallin \& Oskarsson 2002), Juånäs (Engelmark 1978), Hotingsmyran and Råinget (this study) Filitjärn (Wallin 1996) and Bölestjärn (Wallin unpubl.). Grazing stands for the sum of taxa indicating forest grazing: Achillea t., Alchemilla t., Artemisia vulgaris t., Asteraceae undiff., Campanula t., Compositae, Epilobium t., Juniperus t., Melampyrum, Plantago lanceolata, Plantago media/major, Polygonum aviculare, Polygonum bistorta t., Ranunculus t., Rumex acetosa/acetosella (c.f. Behre 1981). Filitjärn and Bölestjärn are varved lakes dated by varve counting. The other sites are small mires and age determination is made by radiocarbon dating. Bölestjärn and Ändsjömyren are located close to present day agricultural fields. The other sites are situated on forest land. 
Therefore, it is more likely that the changes were caused by a continual pastoral impact of a more or less local domestic forest grazing. Extensive, small-scale and nomadic reindeer herding is therefore less likely to have induced the vegetation changes. Current pollen studies that have identified vegetation changes induced by reindeer grazing and that are similar to this study come from sites with more intense reindeer grazing, i.e., reindeer pens (Aronsson 1991) and winter villages (Hicks 1993), and therefore we regard these results not applicable here.

Agrarian use has long been viewed as synonymous with the cultivation of cereals. That is true for the Mälaren region, the coast of Norrland, and partly for the Storsjön area in Jämtland, where the first signs of forest grazing coincide with cereal cultivation (Fig. 5). But in central Norrland conditions for cereal cultivation were less favourable, and animal husbandry could thus offer a more rational form of land use. Therefore changes in pollen diagrams from mid-boreal Sweden interpreted as human impact do not necessarily have to include Cerealia (cf. Hicks 1985, 1998). In pollen analyses adjacent to a settlement the pollen signal from a forest pasture can be hard to separate from the general pollen noise from human impact around the settlement.

Studies from Dalarna (Emanuelsson \& Segerström 1998), Värmland (Emanuelsson et al. 2003) and Hälsingland (Emanuelsson et al. 2000; Karlsson \& Emanuelsson 2002, Liases 2003) show that forest grazing in the Iron Age often was connected to shielings (Sw. fäbodar). A shieling system (Sw. säterbruk) presupposes a known shieling site as well as a link to a farm or village (Emanuelsson et al. 2000; Karlsson \& Emanuelsson 2000). Any conclusions on whether the areas around Råmyren and Hotingsmyran were part of a shieling system or not are therefore ambiguous, since Iron Age settlements are absent. However, studies of shielings have often shown cereal cultivation in connection with pasture (Emanuelsson et al. 2000, 2003; Karlsson \& Emanuelsson 2000), and this is found at neither Råmyren nor Hotingsmyran.

\section{IRON AND CAPITALISM}

Another important factor in the Iron Age in central Norrland is the production of iron and trading in iron. Since Gert Magnusson's research it has been generally known that iron production was extensive in Jämtland especially during the early Iron Age, in Hälsingland and Dalarna during the late Iron Age, and in Härjedalen c. AD 1300-1600 (Magnusson 1986). Moreover, when the Swedish National Heritage Board conducted an inventory of prehistoric finds in 1993, a large number of large and small iron-working sites were identified in Medelpad as well (Fig. 6). A blast furnace dated to $\mathrm{AD} 450-660$ has been excavated at a mire in Torp parish in Medelpad (Nykvist 1995). A number of finds of deposits of spadeshaped iron bars have been recorded from the Migration Period to the Viking Age in Jämtland and Medelpad (Fig. 7). What relationship is there between our discussion about subsistence in the inland region and about the ideology of the graves and the research on iron working? 


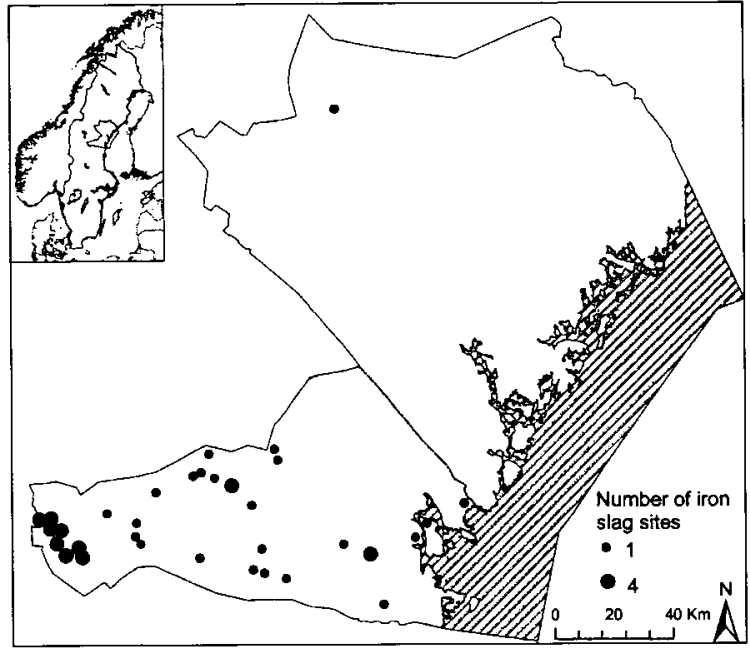

Fig. 6. Distribution of iron slag sites in the county Västernorrland (Medelpad and Angermanland). Afier a map made by Pia Nykvist, Länsmuseet Västernorrland.

In figure 8 the map of identified grave-settings in Norrland shows a clear difference between the dispersal of graves in central Norrland and the lack of graves in northern Norrland. Even if we take into account the few identified single graves in the north that have not been shown on the map, the difference is complete.

A mass of Iron Age finds, hearths and hunting traps in the north indicates, however, that the far north was not void of people; on the contrary, its population is well substantiated. It is the burial practices of central Norrland and northern Norrland that differ. Our discussion of agrarian subsistence and gravesettings in central Norrland demonstrates that there are clear links between the inland region and the coastal areas. But there are also clear differences evidenced in the well-known great barrows and halls that cannot be found inland apart from in the Storsjön area (Ramqvist 1983, 1992). This difference arises during the first centuries $\mathrm{AD}$ and persists during the entire Iron Age.

The most important reason for both the similarities and the differences between the coastal and inland settlements in central Norrland can be sought in the development of inland iron production. This was already under way around $\mathrm{AD}$ 1 and increased greatly during the $3^{\text {rd }}$ century in Jämtland to reach its zenith during the Migration Period (Fig. 9). According to the later results of the inventory of prehistoric remains, there are a great many occurrences of iron slag in Medel-

Fig. 7. Distribution of spade-shaped iron bars found in Scandinavia. After Hallinder 1978:Fig. 3.

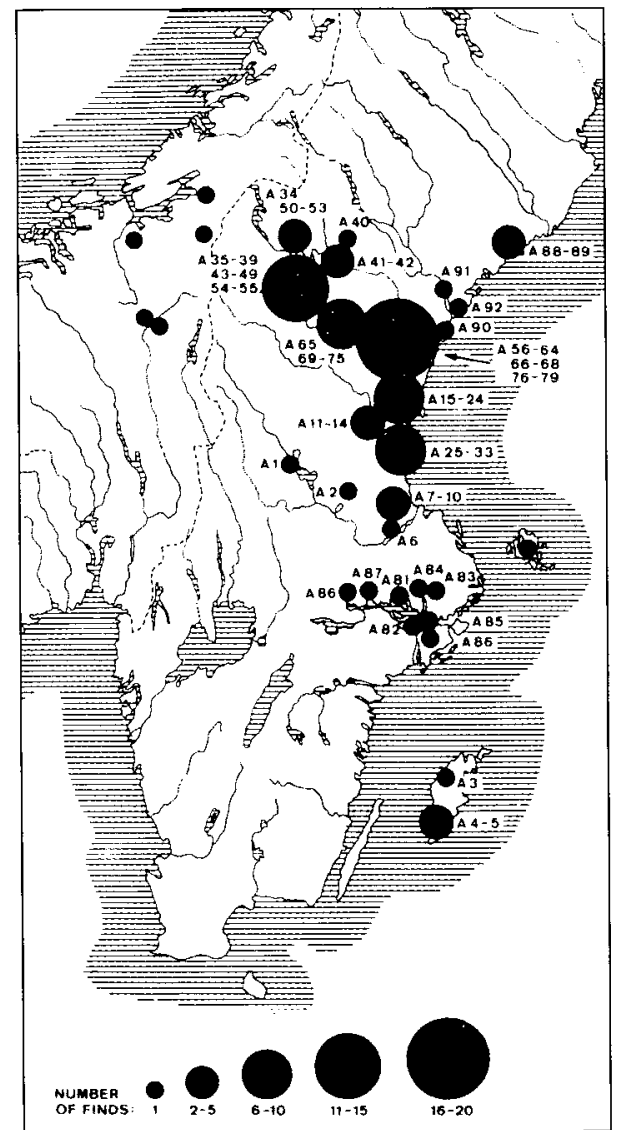




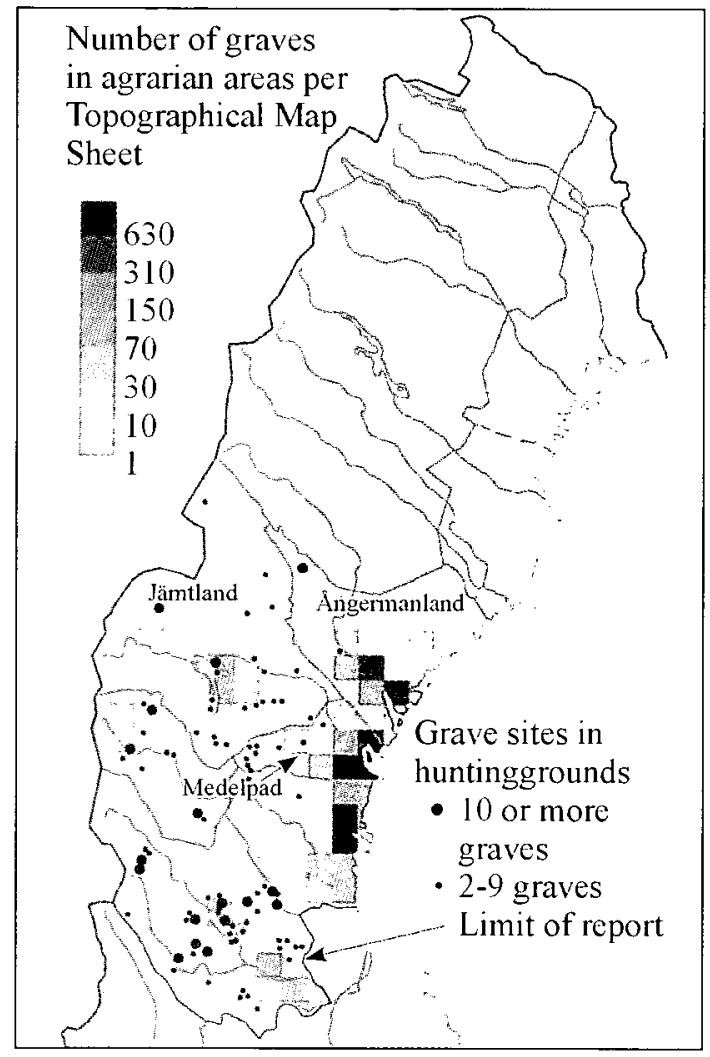

Fig. 8. Iron Age graves in Norrland and Dalarna. Grave sites with only one grave are not marked. After Selinge 1994:33.

pad and very few in Ångermanland (Fig. 7). This difference is corroborated by the long-established dispersal of spade-shaped iron ingots along the Ljungan river in Medelpad (Fig. 6). A similar dispersal can be discerned in the relatively numerous Iron Age graves in inland Medelpad and the few found in inland Angermanland (Fig. 8). Similar comparisons can be made between the results of environmental history studies in Medelpad and Ångermanland. In inland Medelpad evidence has been found of a type of agrarian culture with both forest grazing and cultivation (Engelmark 1978) whereas inland Ångermanland has only traces of forest grazing (this study).

The similarities in both the conceptual world of ideology and the subsistence in inland Medelpad and the coast underlie the exploitation of inland deposits of iron. The production and transport of iron was the mainstay of an economic system that required or was at least promoted by shared ideology and forms of subsistence. It is not possible to determine whether this means that groups moved inland from the coast, or if inland dwellers adopted the ideology and mode of subsistence of the coastal peoples, or if we are dealing with a combination of the two. The great barrows and halls in the coastal region and the settled area around

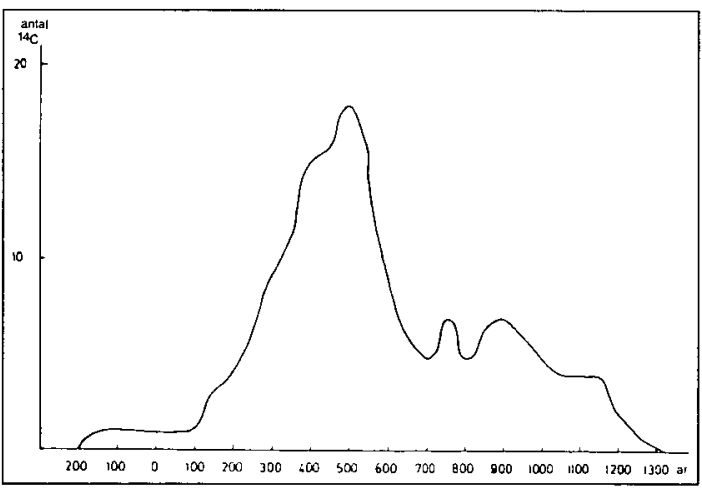

Storsjön are the social and ideological expressions of the economic system, an example of Iron Age capitalism.

In North America the concept of capitalism has been used for understanding problems in the archaeology of the historical period

Fig. 9. The complete radiocarbon datings from iron production sites on the lake shores in Jämtland. After Magnusson 1986:Fig. 96. 
(Leone \& Potter 1999). In his basic definition of capitalist society in modern historical archaeology, Mark P. Leone (1999:4) writes:

Capitalistic society is characterized by owners, governments, and their agents continuously introducing technical changes that alter the structure of labor, and pushing these changes into areas, cultures, and classes where they did not exist before, or where they become intensified. Owners and their agents expand markets in a deliberate search for customers, as well as for other peoples' resources, including labor, so as to bring them into the production process.

In the case of central Norrland it could be said that the introduction of inland iron production required the acceptance by the local population of the ideology and form of subsistence that prevailed in the coastal areas, if the cooperation was to function. If so, the difference between those with power and those dependent on them was expressed not only by the great barrows and halls on the coast but also by the inland population's not being allowed to erect great barrows and halls of their own. In that case the social relationships of capitalism are the reason that archaeologists are unable to find distinct Iron Age settlements inland apart from in the Storsjön region. The uneven dispersal of inland graves, with the emphasis on Medelpad and Jämtland-Härjedalen and few in Ångermanland, could also be explained. The large parts of inland Angermanland that lacked graves and their accompanying ideology, and that had forest grazing without cultivation, were excluded from the social system of the areas with an economy based on iron. This exclusion also applies to the burial-ground at Långön by Hotingssjön with its grave-goods that indicate long-distance trade/exchange (Hvarfner 1966; Ramqvist 2001:8-9). Traffic in furs may have played a decisive role in its location. But trapping animals and trading in skins did not give rise to the need for a shared ideology and social relationships to the same extent as iron production and distribution did.

\section{CONCLUSION}

Environmental history studies have established that inland subsistence in central Norrland during the Iron Age was characterised by diversity and flexibility, not by a uniform and static hunter-gatherer culture. In the southern parts of the region there is evidence that shielings may have existed during the Iron Age. The numerous hunting pits, some of which date to the Iron Age, do not imply that the inland dwellers devoted all their time to hunting. The new pollen analyses that have been published suggest, as do earlier studies, that extensive forest grazing was widespread throughout central Norrland. The osteological finds from domestic animals also suggest that forest grazing took place. Grave-settings in the coast and the interior display both differences and similarities; on the other hand, their underlying ideological concepts are the same. Iron production in Jämtland and Medelpad, as indicated by slag deposits and spade-shaped iron bars, played a decisive role for the economic and social development of central Norrland. The 
modes of subsistence, ideology and iron production in the interior indicate a unity dependent on coastal power. The economy and the social system in the entire region can be viewed as elements of an early capitalist system, which also explains the uneven dispersal of prehistoric remains in the interior.

\section{English revised by Laura Wrang.}

\section{ACKNOWLEDGMENTS}

We would especially like to thank Ulf Segerström but also Jan-Erik Wallin and Roger Engelmark for major contributions to the project. We wish to thank Pia Nykvist, Länsmuseet, Västernorrland for providing data on the distribution of iron slag sites, and David Jones for the English translation and linguistic improvement. The study was funded by Kungl. Vitterhets Historie och Antikvitets Akademien (the Royal Academy of Letters, History and Antiquities).

\section{REFERENCES}

Ambrosiani, B. 1964. Fornlämningar och bebyggelse. Studier i Attundalands och Södertörns förhistoria. Uppsala.

Ambrosiani, B., Iregren, E. \& Lahtiperä, P. 1984. Gravfält i fångstmarken. Undersökningar på Smalnäset och Krankmärtenhögen, Härjedalen. Riksantikvarieämbetet och Statens historiska museer. Rapport 1984:6. Stockholm.

Aronsson, K-A. 1991. Forest reindeer herding A.D. 1-1800. Archaeology and Environment 10. Umeå.

Baudou, E. 1978. Den förhistoriska fångstkulturen i Västernorrland. In: Baudou, E. \& Selinge, K-G. Västernorrlands Förhistoria. Pp. 11-152. Härnösand.

- 1989. Hög - gård - helgedom i Mellannorrland under den äldre järnåldern. Arkeologi i norr 2. Pp. 9-43.

- 1991. Helgedom, hus och hög. In: Lagerlöf, A. (Ed) Gravfältsundersökningar och gravarkeologi. Forskning för kulturmiljövård 3. Pp. 71-82. Stockholm.

- 2002. Arkeologi och ortnamnsforskning. Namn och Bygd. Vol. 90. Pp. 6-36.

Behre, K-E. 1981. The interpretation of anthropogenic indicators in pollen diagrams. Pollen et Spores. Vol. 23. Pp. 226-245.

Bellander, E. 1939. Gästriklands järnåldersbebyggelse. 1. Fornlämningar och fynd. Från Gästrikland 1938. Gävle.

Bolin, H. 2001. Två undersökta gravfält i Norrlands inland. En diskussion kring forntida kulturtraditioner i fjällnära miljöer. In: Bolin, H. \& Edenmo, R. Övre Grundsjön, Vojmsjön och Lilla Mark. Rapport över arkeologiska undersökningar: Projekt uppdragsarkeologi. Pp. 6-30. Stockholm.

Elveland, J. \& Sjöberg K. 1981 . Norrländska våtslåttermarker - Växt- och djurliv förr och nu. Fauna och flora. Vol. 76. Pp. 21-30.

Emanuelsson. M. 2001. Settlement and Land-Use History in the Central Swedish Forest Region. The use of pollen analysis in interdisciplinary studies. Acta Universitatis Agriculturae Sueciae. Silvestria 223. Umeå.

Emanuelsson. M., Bergquist, U., Segerström, U., Svensson, E. \& von Stedingk, H. 2000. Shieling or Something Else? Iron Age and Medieval Forest Settlement and Land Use at Gammelvallen in Ängersjö, Central Sweden. Lund Archaeological Review. Vol. 6. Pp.123-138. 
Emanuelsson. M., Johansson, A., Nilsson, S., Pettersson, S. \& Svensson, E. 2003. Settlement, Shieling and Landscape. The Local History of a Forest Hamlet. Lund Studies in Medieval Archaeology 32. Lund.

Emanuelsson. M. \& Segerström U. 1998. Forest grazing and outland exploitation during the Middle Ages in Dalarna, Central Sweden: a study based on pollen analysis. In Andersson, H., Ersgård, L. \& Svensson, E. Outland Use in Preindustrial Europe. Lund Studies in Medieval Archaeology 20. Pp. 80-94. Lund.

Engelmark, R. 1978. The Comparative Vegetational History of Inland and Coastal Sites in Medelpad, N. Sweden, during the Iron Age. In: Baudou, E., Engelmark, R., Olsson, I.U. \& Renberg, I. Archaeological and Palaeoecological Studies in Medelpad, N. Sweden. Early Norrland 11. KVHAA. Pp. 25-62. Stockholm.

Forsberg, L. 2001. Keramiken från Råingetlokalerna. Mångfald i tid och formspråk. Tidsspår. Forntidsvärld och gränslöst kulturarv. Pp. 129-150. Härnösand.

George, O. 2001. Boplatsen vid Råinget. In: Bergvall, M. \& George, O. (Eds). Tidsspår. Forntidsvärld och gränslöst kulturarv. Pp. 105-128. Härnösand.

Hallinder, P. 1978. Spade-shaped Currency Bars. In: Lamm, K. \& Lundström, A. (Eds). Excavations at Helgö V:1. Pp. 30-37. Stockholm.

Hicks, S. 1985. Problems and possibilities in correlating historical/archaeological and pollen-analytical evidence in a northern boreal environment: an example from Kuusamo, Finland. Fennoscandia archaeologica II. Pp. 51-84.

- 1991. Large and small scale distribution of pollen in the boreal zone. In: Hicks, S., Miller, U., Nilsson S. \& Vuorela, I. Airborne particles and gases, and their impact on the cultural heritage and its environment. Pact 33. Pp. 17-25. Strasbourg.

- 1993. Pollen evidence of localized impact on the vegetation of northernmost Finland by hunter-gatherers. Vegetation History and Archaeobotany. Vol 2. Pp. 137-144.

- 1998. Fields, boreal forest and forest clearings as recorded by modern pollen deposition. In: Gaillard, MJ. \& Berglund, B.E. (Eds). Quantification of land surface cleared from forests during the HoloceneModern pollen/vegetation/landscape relationships as an aid to the intercomparison of fossil pollen data. Paläoklimaforschung. Band 27. Pp. 53-66. Stuttgart.

Hjortsberg, K. 1978. The Archaeological Investigations at L. Holmsjön. The Excavation in 1972. In: Baudou, E., Engelmark, R. Olsson, I.U. \& Renberg. I., Archaeological and Palaeoecological Studies in Medelpad, N. Sweden. Early Norrland 11. KVHAA. Pp. 10-18. Stockholm.

Hulthén, B. 1991. On Ceramic Ware in Northern Scandinavia during the Neolithic, Bronze and Early Iron Age. A Ceramic-Ecological Study. Archaeology and Environment 8. Umeå.

Huttunen, P. \& Tolonen, M. 1972. Pollen-Analytical Studies of Prehistoric Agriculture in Northern Ångermanland. In: Huttunen, P., Olsson, I.U., Tolonen, K. \& Tolonen, M. Palaeoecological Investigations in Northern Sweden. Early Norrland 1. KVHAA. Pp. 9-34. Stockholm.

Hvarfner, H. 1957. Fångstmän och nybyggare i Angermanälvens källområden under järnåldern. Stockholm.

- 1966. A Viking Settlement in the Forest Area. In: Janson, S. \& Hvarfner, H. Ancient Hunters and Settlements in the Mountains of Sweden. Pp. 43-51. Stockholm.

Hyenstrand, $\AA$. 1987. Forntid i gränsland. In: Björklund, S. (Ed). Lima och Transtrand. Ur två socknars historia 2. Pp. 109-166. Malung.

Hårding, B. 2005. Nos och näbb och klöv och klo. In: Karlenby, L. (Ed). Tidens resenärer. Arkeologiska händelser längs vägen mellan Köping och Kolsva. Pp.153-168. Riksantikvarieämbetet. Stockholm.

Hårding, B., \& Kraft, A. 1997. Osteologisk undersökning av en skärvstenslokal i Sneden, Litslena sn, Uppland. In: Fagerlund, D. Skärvstenshögar i Sneden. En långvarig historia-på sidan om. Arkeologiska undersökningar. UV Uppsala Rapport 1997:48. Pp. 63-72. Uppsala.

Iregren, E. 1984. Catalogue of Bone Remains on Prehistoric Sites in Northern Sweden. In: Ekman, J. \& Iregren, E. Archaeo-Zoological Investigations in Northern Sweden. Early Norrland 8. KVHAA. Pp. 43-99. Stockholm.

Jacobson, G.L.J. \& Bradshaw, R.H.W. 1981. The selection of sites for paleovegetational studies. Quaternary Research. Vol. 16. Pp. 80-96. 
Johansson, E. 2002. (Ed) Periferins landskap. Historiska spår och nutida blickfält i svensk glesbygd. Skrifter från forskningsprojektet Flexibilitet som tradition, Ängersjöprojektet 7. Lund.

Karlsson, H. \& Emanuelsson M. 2002. Fäbodväsendets långa historia. In: Johansson, E. Periferins landskap. Historiska spår och nutida blickfält i svensk glesbygd. Skrifter från forskningsprojektet Flexibilitet som tradition, Ängersjöprojektet 7. Pp. 123-140. Lund.

Leone, M.P. 1999. Setting Some Terms for Historical Archaeologies of Capitalism. In: Leone, M.P. \& Potter, P.B. Jr. (Eds). Historical Archaeologies of Capitalism. Pp. 3-20. New York.

- \& Potter, P.B. Jr. (Eds).1999. Historical Archaeologies of Capitalism. New York.

Liases, K. 2003. Torkelsbovallen - ett skogsbete från yngre järnålder. Fornvännen. Vol. 98. Pp. 99-106.

Lindqvist, C. 2001. Nämforsen. Ådalen och Ångermanlandskusten - en gynnsam natur- och kulturmiljö under förhistorisk tid. Tidsspår. Forntidsvärld och gränslöst kulturarv. Härnösand. Pp. 83-104.

Magnussson, G. 1986. Lågteknisk järnhantering i Jämtlands län. Jernkontorets Bergshistoriska Skriftserie $\mathrm{Nr} 22$. Stockholm.

Modin, E. 1961. Gamla Tåsjö. Tredje upplagan. Tåsjö kommun. Tandsbyn.

Moore, P.D., Webb, J.A. \& Collinson, M.E. 1991. Pollen analyses. Oxford.

Niklasson, M \& Granström, A. 2000. Numbers and sizes of fires: Long-term spatially explicit fire history in a Swedish boreal landscape. Ecology. Vol. 81. Pp. 1484-1499.

Nykvist, P. 1995. Arkeologisk undersökning av blästerugn Raä nr 224, på fastigheten Kilen 1:1, Torp socken, Medelpad. Kulturmiljövårdens rapporter 1995:2. Härnösand.

Ohlson, M \& Tryterud E. 2000. Interpretation of the charcoal record in forest soils: forest fires and their production and deposition of macroscopic charcoal. The Holocene. Vol. 10. Pp. 519-525.

Olausson, M. 1995. Det inneslutna rummet - om kultiska hägnader, fornborgar och befästa gårdar $i$ Uppland frän 1300 f.Kr. till Kristi födelse. Riksantikvarieämbetet. Arkeologiska undersökningar. Skrifter 9. Stockholm.

Pitkänen, A., Lehtonen, H. \& Huttunen, P. 1999. Comparison of sedimentary microscopic charcoal particle records in a small lake with dendrochronological data: evidence for the local origin of microscopic charcoal produced by forest fires of low intensity in eastern Finland. The Holocene. Vol. 9. Pp. 559-567.

Ramqvist, P.H. 1983. Gene. On the origin, function and development of sedentary Iron Age settlement in Northern Sweden. Archaeology and Environment 1. Umeå.

- 1992. Högom. The excavations 1949-1984. Archaeology and Environment 15. Umeå.

- 2001. Utbytessystem under det första årtusendet e.Kr. Idéer utgående från tre mellannorrländska älvar. Fornvännen. Vol. 96. Pp. 1-21.

Segerström, U \& Emanuelsson M. 2002. Extensive forest grazing and hay-making on mires - vegetation changes in south-central Sweden due to land use since Medieval times. Vegetation History and Archaeobotany. Vol. 11. Pp. 181-190.

Segerström, U., Hörnberg, G. \& Bradshaw, R. 1996. The 9000-year history of vegetation development and disturbance patterns of a swamp-forest in Dalarna, northern Sweden. Holocene Vol. 6. Pp. 37-48.

Selinge, K.-G. 1979. Agrarian Settlements and Hunting Grounds. A Study of the Prehistoric Culture System in a North Swedish River Valley. Theses and Papers in North-European Archaeology 8. Stockholm.

- 1983. Modeller för landskapsutnyttjande inom fångstkultur och tidig agrarkuitur. Exempel från mellersta Norrland. In: Trondheims-symposiet om midt-og nordskandinavisk kultur 1982. Pp. 73-106. Trondheim.

- 1994. Graves and Iron Age Settlement. In: Selinge, K-G. (Special Ed). Cultural Heritage and Preservation. National Atlas of Sweden. Pp. 28-41. Stockholm.

Stuiver, M. \& Reimer, P.J. 1993. Extended ${ }^{14} \mathrm{C}$ database revised CALIB $3.0{ }^{14} \mathrm{C}$ age calibration program. Radiocarbon. Vol. 35. Pp. 215-230.

Sugita, S. 1994. Pollen Representation of Vegetation in Quaternary Sediments - Theory and Method in Patchy Vegetation. Journal of Ecology. Vol. 82. Pp. 881-897.

Sundström, J. 1994. Järnålder i Jämtlands och Härjedalens făngstland. In: Gullberg, K. (Ed). Järnåldern $i$ Mittnorden. Acta antiqua Ostrobotniensia. Pp. 101-126. Vasa.

- 1997. Järnålder i fångstlandet. In: Zachrisson, I. (Ed) Möten i gränsland. Samer och germaner $i$ Mellanskandinavien. Statens historiska museum. Monographs 4. Pp. 21-26. Stockholm. 
Svensson, E. 1998. Människor i utmark. Lund Studies in Medieval Archaeology 21. Lund.

Ullén, I. 1994. The Power of Case Studies. Interpretation of a Bronze-Age Settlement in Central Sweden. Journal of European Archaeology. Vol. 2. Pp. 249-262.

Wallin, J-E. 1996. History of sedentary farming in Ångermanland, northern Sweden, during the Iron Age and Medieval period based on pollen analytical investigations. Vegetation history and archaeobotany. Vol. 5. Pp. 301-312.

Wallin, J-E. \& Oskarsson B. 2002. Odlingslandskapets framväxt i Storsjöbygden: en miljöhistorisk studie i järnåldersbygd, baserad på pollenanalyser och GIS-baserade kartanalyser. Östersund.

Welinder, S. 1998. Neoliticum - bronsålder 3900-500 f.Kr. In: Welinder, S., Pedersen, E.A., Widgren, M. (Eds). Jordbrukets första femtusen år. Det svenska jordbrukets historia. Pp. 11-236. Stockholm.

Zachrissson, I. 1994. Gravfältet på Långön. Angermanland Medelpad 1994-95. Pp. 139-156.

- 1997a. Möten mellan människor. In: Zachrisson, I. (Ed). Möten i gränsland. Samer och germaner $i$ Mellanskandinavien. Statens historiska museum. Monographs 4. Pp. 221-234. Stockholm.

- 1997b. Varför samiskt? In: Zachrisson, I. (Ed). Möten i gränsland. Samer och germaner i Mellanskandinavien. Statens historiska museum. Monographs 4. Pp. 189-220. Stockholm.

- 2004. Samisk-nordiska kulturkontakter i Mellanskandinavien under 6-700-talen e.Kr. (Vendeltid) - utifrån det arkeologiska materialet. In: Kusmenko, J. (Ed). The Sámi and the Scandinavians. Aspects of 2000 years of contact. Pp. 9-16. Hamburg.

Zackrisson, O. 1977. Influence of forest fires on the North Swedish boreal forest. Oikos. Vol. 29. Pp. 2232. 